\title{
Fe(III) and $S^{0}$ Reduction by Pelobacter carbinolicus
}

\author{
DEREK R. LOVLEY,* ELIZABETH J. P. PHILLIPS, DEBRA J. LONERGAN, AND PEGGY K. WIDMAN
}

\author{
Received 21 December 1994/Accepted 30 March 1995
}

\begin{abstract}
There is a close phylogenetic relationship between Pelobacter species and members of the genera Desulfuromonas and Geobacter, and yet there has been a perplexing lack of physiological similarities. Pelobacter species have been considered to have a fermentative metabolism. In contrast, Desulfuromonas and Geobacter species have a respiratory metabolism with $\mathrm{Fe}$ (III) serving as the common terminal electron acceptor in all species. However, the ability of Pelobacter species to reduce Fe(III) had not been previously evaluated. When a culture of Pelobacter carbinolicus that had grown by fermentation of 2,3-butanediol was inoculated into the same medium supplemented with $\mathrm{Fe}$ (III), the $\mathrm{Fe}$ (III) was reduced. There was less accumulation of ethanol and more production of acetate in the presence of $\mathrm{Fe}(\mathrm{III})$. $P$. carbinolicus grew with ethanol as the sole electron donor and $\mathrm{Fe}$ (III) as the sole electron acceptor. Ethanol was metabolized to acetate. Growth was also possible on Fe(III) with the oxidation of propanol to propionate or butanol to butyrate if acetate was provided as a carbon source. $P$. carbinolicus appears capable of conserving energy to support growth from Fe(III) respiration as it also grew with $\mathrm{H}_{2}$ or formate as the electron donor and $\mathrm{Fe}$ (III) as the electron acceptor. Once adapted to $\mathrm{Fe}$ (III) reduction, $P$. carbinolicus could also grow on ethanol or $\mathbf{H}_{2}$ with $\mathbf{S}^{0}$ as the electron acceptor. $P$. carbinolicus did not contain detectable concentrations of the $c$-type cytochromes that previous studies have suggested are involved in electron transport to $\mathrm{Fe}$ (III) in other organisms that conserve energy to support growth from $\mathrm{Fe}($ III) reduction. These results demonstrate that $P$. carbinolicus may survive in some sediments as an $\mathrm{Fe}$ (III) or $S^{\mathbf{0}}$ reducer rather than growing fermentatively on rare substrates or syntrophically as an ethanol-oxidizing acetogen. These studies also suggest that the ability to use Fe(III) as a terminal electron acceptor may be an important unifying feature of the Geobacter-Desulfuromonas-Pelobacter branch of the delta Proteobacteria.
\end{abstract}

The genus Pelobacter encompasses a unique group of fermentative microorganisms in the delta Proteobacteria (54). The original characterization of these organisms suggested that they could grow only by fermentation of a limited range of substrates that are relatively rare in most anaerobic environments (52-56). Fermentable substrates include 2,3-butanediol and acetoin, which most Pelobacter species (Pelobacter carbinolicus, Pelobacter venetianus, Pelobacter acetylenicus, and Pelobacter propionicus) can ferment. Some Pelobacter species can also ferment ethylene glycol (P. carbinolicus and $P$. venetianus), polyethylene glycol ( $P$. venetianus), acetylene ( $P$. acetylenicus), or gallic acid and related compounds (Pelobacter acidigallici). Sugars and other common fermentable substrates are not metabolized. $P$. carbinolicus, $P$. venetianus, and $P$. acetylenicus can also grow in coculture with $\mathrm{H}_{2}$-consuming microorganisms by oxidizing ethanol, propanol, or butanol to the corresponding acid with the production of $\mathrm{H}_{2}(52,53,56)$. None of the Pelobacter species were found to use any of the potential physiological electron acceptors typically considered at that time. Thus, it was assumed that these organisms could conserve energy only through substrate-level phosphorylation.

Phylogenetic analyses based on 16S rRNA oligonucleotide cataloging $(57)$ or sequencing $(16,26)$ have indicated that the members of the genus Pelobacter are phylogenetically intertwined with members of the genus Desulfuromonas. Some Pelobacter species are more closely related to Desulfuromonas species than to other Pelobacter species. Yet members of the genus Desulfuromonas are respiratory organisms which couple the oxidation of simple organic compounds to the reduction of $S^{0}(60)$. That two apparently different physiological groups would be so phylogenetically interrelated is surprising and un-

\footnotetext{
* Corresponding author. Mailing address: 430 National Center, U.S.
} Geological Survey, Reston, VA 22092. Phone: (703) 648-5825. Fax: (703) 649-5484. Electronic mail address: dlovley@stress.er.usgs.gov. precedented (57) and has been difficult to justify in terms of biochemical evolution $(57,60)$.

After the discovery of the Pelobacter species, anaerobic microorganisms which could conserve energy to support growth by coupling the oxidation of organic compounds to the reduction of $\mathrm{Fe}(\mathrm{III})$ were discovered $(35,39)$. The first of these organisms, Geobacter metallireducens, is closely related to Desulfuromonas acetoxidans (30). Although $G$. metallireducens cannot grow via $S^{0}$ reduction, it was found that $D$. acetoxidans can grow via $\mathrm{Fe}$ (III) reduction (50). In fact, at the time, $D$. acetoxidans was only the second organism known to be able to couple the complete oxidation of multicarbon compounds to the reduction of $\mathrm{Fe}(\mathrm{III})$. These results with $D$. acetoxidans illustrated the potential for phylogenetic analysis based on $16 \mathrm{~S}$ rRNA sequences to predict previously unsuspected physiological traits. Since then, a number of other acetate-oxidizing, $\mathrm{Fe}(\mathrm{III})$-reducing microorganisms which are closely related to $G$. metallireducens and D. acetoxidans have been isolated. These include Geobacter sulfurreducens, isolated from a drainage ditch (8); Geobacter hydrogenophilus, isolated from a petroleum-contaminated aquifer (10); Desulfuromonas palmitatis, isolated from marine sediments (11); and Geobacter chapellei, isolated from the deep subsurface (10). Although some Geobacter and Desulfuromonas species can grow via $\mathrm{S}^{0}$, nitrate, or fumarate reduction, not all can. One trait that all Geobacter and Desulfuromonas species do share is the ability to use $\mathrm{Fe}(\mathrm{III})$ as a terminal electron acceptor.

Thus, we hypothesized that the capacity for Fe(III) respiration might be the central physiological characteristic held in common among the Geobacter, Desulfuromonas, and $\mathrm{Pe}$ lobacter species. To further investigate this, the ability of $P$. carbinolicus to use $\mathrm{Fe}$ (III) as an electron acceptor was evaluated. This species of Pelobacter was chosen because it is one of a group of three pelobacters (including $P$. acetylenicus and $P$. venetianus) that, according to $16 \mathrm{~S}$ rRNA analysis and DNADNA homologies $(16,57)$, are most closely related to $D$. ace- 
toxidans. Furthermore, oligonucleotide cataloging (57) has indicated that $P$. carbinolicus is the closest known relative of a freshwater strain of Desulfuromonas, Desulfuromonas acetexigens (19), which can also conserve energy to support growth from Fe(III) reduction $(11,50)$. Here we report that $P$. carbinolicus can use $\mathrm{Fe}(\mathrm{III})$ as a terminal electron acceptor and that, once adapted to $\mathrm{Fe}(\mathrm{III})$ reduction, it was also capable of reducing $\mathrm{S}^{0}$. In addition to expanding the potential environmental significance of $P$. carbinolicus, these findings are of physiological interest because $P$. carbinolicus appears to lack the $c$-type cytochromes (52) that previously $(1,13,30,44,46,50)$ have been considered to be involved in energy-conserving electron transport in dissimilatory Fe(III)-reducing bacteria.

\section{MATERIALS AND METHODS}

Culturing techniques. Strict anaerobic culturing techniques $(4,22,43)$ were used throughout as previously described (35). Two cultures of $P$. carbinolicus (DSM 2380) and a culture of D. acetexigens (DSM 1397) were purchased from the German Collection of Microorganisms (DSM), Braunschweig, Germany. G. metallireducens was from our culture collection.

D. acetexigens was grown in the medium suggested by the DSM for culturing this organism with fumarate as the electron acceptor. G. metallireducens was grown in acetate-Fe(III) citrate medium as previously described (35). P. carbinolicus was grown in a modified version of the medium suggested for this organism by the DSM. The medium contained (in grams per liter of water) $\mathrm{NaHCO}_{3}(2.5)$, $\mathrm{NH}_{4} \mathrm{Cl}(0.25), \mathrm{KCl}(0.5), \mathrm{KH}_{2} \mathrm{PO}_{4}(0.2), \mathrm{NaCl}(20), \mathrm{MgCl}_{2} \cdot 6 \mathrm{H}_{2} \mathrm{O}$ (2), and $\mathrm{CaCl}_{2} \cdot 2 \mathrm{H}_{2} \mathrm{O}(0.15)$, as well as a trace metal solution (32). The major difference in the medium from the one suggested by DSM was that there was nitrilotriacetic acid (NTA) and tungstate in the trace metal mixture. The medium was dispensed into pressure tubes $(10 \mathrm{ml})$ or $160-\mathrm{ml}$ serum bottles $(100 \mathrm{ml})$, bubbled with $\mathrm{N}_{2}-\mathrm{CO}_{2}(80: 20)$ for $5 \mathrm{~min}$ (pressure tubes) or $15 \mathrm{~min}$ (serum bottles), and then sealed with thick butyl rubber stoppers. The medium was sterilized by autoclaving. The medium $\mathrm{pH}$ was ca 6.8 .

All other additions were made to the cooled, sterile medium immediately prior to inoculation from anoxic sterile aqueous stocks. Except where noted, sodium sulfide $(1.7 \mathrm{mM})$ was added as a reductant. $\mathrm{FeCl}_{2}(2.5 \mathrm{mM})$ was added as a reductant in the initial studies on growth on colloidal $\mathrm{S}^{0}$. The following electron donors were added where noted at a final concentration of $10 \mathrm{mM}$ : 2,3-butanediol, ethanol, propanol, butanol, or formate. $\mathrm{H}_{2}$ was added at $60 \mathrm{kPa}$. Acetate $(5$ $\mathrm{mM}$ ) was added as a carbon source for growth on $\mathrm{H}_{2}$, formate, propanol, and butanol. Fe(III) forms evaluated included poorly crystalline Fe(III) oxide (100 $\mathrm{mmol} /$ liter) prepared as previously described (33), Fe(III)-NTA (20 mM) (50), and $\mathrm{Fe}$ (III)-citrate $(10 \mathrm{mM}) . \mathrm{S}^{0}$ forms evaluated were colloidal $\mathrm{S}^{0}(5)$ (ca. $3 \mathrm{mM}$ ) and sublimed sulfur (ca. $20 \mathrm{~g} /$ liter). Cultures were incubated at $30^{\circ} \mathrm{C}$ in the dark.

For the cell suspension study, cells were grown on 2,3-butanediol in serum bottles and then harvested under $\mathrm{N}_{2}-\mathrm{CO}_{2}(80: 20)$ by centrifugation in sealed bottles. The cells were resuspended in an anoxic marine salts, bicarbonate buffer that contained (in grams per liter) $\mathrm{NaHCO}_{3}(2.5), \mathrm{NaCl}(20), \mathrm{MgCL}_{2} \cdot 6 \mathrm{H}_{2} \mathrm{O}(2)$, $\mathrm{KCl}(0.5)$, and $\mathrm{CaCl}_{2}(0.1)$. The cells were again collected by centrifugation and resuspended in the buffer. An aliquot of the concentrated cells $(3.5 \mathrm{mg}$ of protein) was added to anoxic bicarbonate buffer (10 $\mathrm{ml}$ in $25-\mathrm{ml}$ serum bottles) amended with $\mathrm{Fe}(\mathrm{III})-\mathrm{NTA}(20 \mathrm{mM})$. One set of cells was preincubated at $80^{\circ} \mathrm{C}$ for $20 \mathrm{~min}$ and then added to buffer and incubated at $80^{\circ} \mathrm{C}$ in order to inhibit enzymatic activity. Fe(II) production was monitored by removing aliquots over time and analyzing for $\mathrm{Fe}(\mathrm{II})$ as outlined below.

Growth experiments were carried out in $10-\mathrm{ml}$ cultures in anaerobic pressure tubes. For growth on $\mathrm{H}_{2}$, the tubes were incubated horizontally to promote gas transfer. Aliquots were removed over time and analyzed for cell numbers, Fe(II) or sulfide, or electron donor and product concentrations.

Analytical techniques. Concentrations of $\mathrm{HCl}$-extractable $\mathrm{Fe}(\mathrm{II})$ in the cultures were monitored with ferrozine as previously described (35). For the cell suspension study, the samples were not treated with $\mathrm{HCl}$ but were added directly to buffer containing ferrozine. Sulfide was analyzed colorimetrically with the methylene blue method (9). Cell numbers were determined with epifluorescent microscopy (21). $\mathrm{H}_{2}$ concentrations in the headspace of cultures were measured with a reduction gas analyzer (31). Acetate, ethanol, propanol, butanol, and 2,3-butanediol were analyzed in samples filtered through a $0.2-\mu \mathrm{m}$-pore-diameter filter (Gelman Acrodisc) with high-pressure liquid chromatography on an Aminex HPX-87H column (Bio-Rad) with $0.01 \mathrm{~N} \mathrm{H}_{2} \mathrm{SO}_{4}$ as the eluant and a differential refractometer detector. Concentrations of protein in cell suspensions were determined by digesting the samples in $1 \mathrm{~N} \mathrm{NaOH}$ for 5 min at $100^{\circ} \mathrm{C}$ and measuring protein with the Lowry method (41).

Cytochrome content. Dithionite-reduced minus air-oxidized difference spectra of washed suspensions of cells that had been grown fermentatively on butanediol or with ethanol or $\mathrm{H}_{2}$ as the electron donor and $\mathrm{Fe}(\mathrm{III})$ or $\mathrm{S}^{0}$ as the electron acceptor were measured as previously described (30).

16S rRNA gene sequencing. Nucleic acids were isolated as previously de-

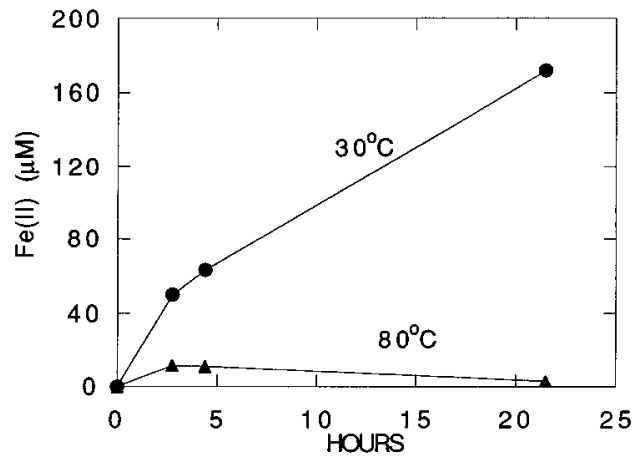

FIG. 1. Fe(II) production over time when washed cell suspensions of $P$. carbinolicus (3.5 mg of protein) were suspended in $10 \mathrm{ml}$ of a marine salts, bicarbonate buffer with $\mathrm{Fe}(\mathrm{III})-\mathrm{NTA}(20 \mathrm{mM})$ as the potential electron acceptor The buffer composition was (in grams per liter) $\mathrm{NaHCO}_{3}(2.5), \mathrm{NaCl}(20)$, $\mathrm{MgCl}_{2} \cdot 6 \mathrm{H}_{2} \mathrm{O}(2), \mathrm{KCl}(0.5)$, and $\mathrm{CaCl}_{2}(0.1)$.

scribed (2) and treated with RNase. The genes coding for 16S rRNA of $P$. carbinolicus were amplified by using eubacterial primer 50F (5'-AACACATG CAAGTCGAACG-3') (23) and universal primer 1492R (5'-GGTTACCTTGT TACGACTT- $\left.3^{\prime}\right)(15,58)$. The genes coding for $16 \mathrm{~S}$ rRNA of $D$. acetexigens were amplified by using 50F and universal primer 1391R (24). The PCR products of genes coding for 16S rRNA were purified with a Wizard PCR Prep System (Promega Corp., Madison, Wis.) and resuspended in sterile water. Both strands of the purified PCR products were sequenced by automated dye dideoxy terminator sequencing at Michigan State University Sequencing Facility with a 373A DNA sequencing system (Applied Biosystems, Foster City, Calif.). Oligonucleotides complementary to the conserved regions of the eubacterial 16S rRNA were chosen to prime the sequencing reactions and were synthesized on either a model 394 DNA-RNA synthesizer or a model 380B DNA synthesizer (Applied Biosystems). Sequence alignments were either performed manually or obtained from the Ribosomal Data Base Project (25). Phylogenetic trees were inferred by the maximum likelihood method $(17,25,48)$. Statistical significance of the branching pattern was determined by bootstrap analysis.

Nucleotide sequence accession number. The accession numbers for GenBank and EMBL sequences used in the phylogenetic analysis are as follows: D. acetexigens, U23140; D. acetoxidans, M26634; Desulfuromusa bakii, X79412; Desulfuromusa kysingii, X79414; Desulfuromusa succinoxidans, X79415; Desulfovibrio desulfuricans, M34113; Desulfovibrio vulgaris, M34399; G. metallireducens, L07834; G. sulfurreducens, U13928; P. acetylenicus, X70955; P. acidigallici, X77216; P. carbinolicus, U23141; P. propionicus, X70954; Shewanella alga, X81621; and Shewanella putrefaciens, X81623.

\section{RESULTS}

$\mathrm{Fe}$ (III) reduction with 2,3-butanediol, alcohols, and $\mathbf{H}_{2}$. Washed cell suspensions of $P$. carbinolicus reduced Fe(III)NTA, and this activity appeared to be enzymatic as it was inhibited by incubating the cells at $80^{\circ} \mathrm{C}$ (Fig. 1). Fe(III) was also reduced when $P$. carbinolicus grown on 2,3-butanediol was inoculated into 2,3-butanediol growth medium amended with $\mathrm{Fe}(\mathrm{III})$ (Fig. 2A). In the presence of $\mathrm{Fe}(\mathrm{III})$, less ethanol and more acetate were produced than in 2,3-butanediol medium without $\mathrm{Fe}$ (III) (Fig. 2B).

$P$. carbinolicus grew in medium with ethanol as the sole electron donor and $\mathrm{Fe}$ (III) as the electron acceptor (Fig. 3). Cell growth coincided with $\mathrm{Fe}$ (III) reduction. Ethanol was converted to acetate. The ratio of $\mathrm{Fe}$ (II) produced to acetate produced was 3.8 , which suggests that ethanol was oxidized according to the following: $\mathrm{CH}_{3} \mathrm{CH}_{2} \mathrm{OH}+4 \mathrm{Fe}(\mathrm{III})+$ $\mathrm{H}_{2} \mathrm{O} \rightarrow \mathrm{CH}_{3} \mathrm{COO}^{-}+4 \mathrm{Fe}(\mathrm{II})+5 \mathrm{H}^{+}$. P. carbinolicus also oxidized propanol and butanol to the corresponding fatty acids with $\mathrm{Fe}(\mathrm{III})$ serving as the electron acceptor, but acetate was required as a carbon source for growth on these substrates. In addition to growing in the medium at marine salinity, $P$. carbinolicus also grew with ethanol as the electron donor and $\mathrm{Fe}(\mathrm{III})$ as the electron acceptor in freshwater medium. With ethanol 

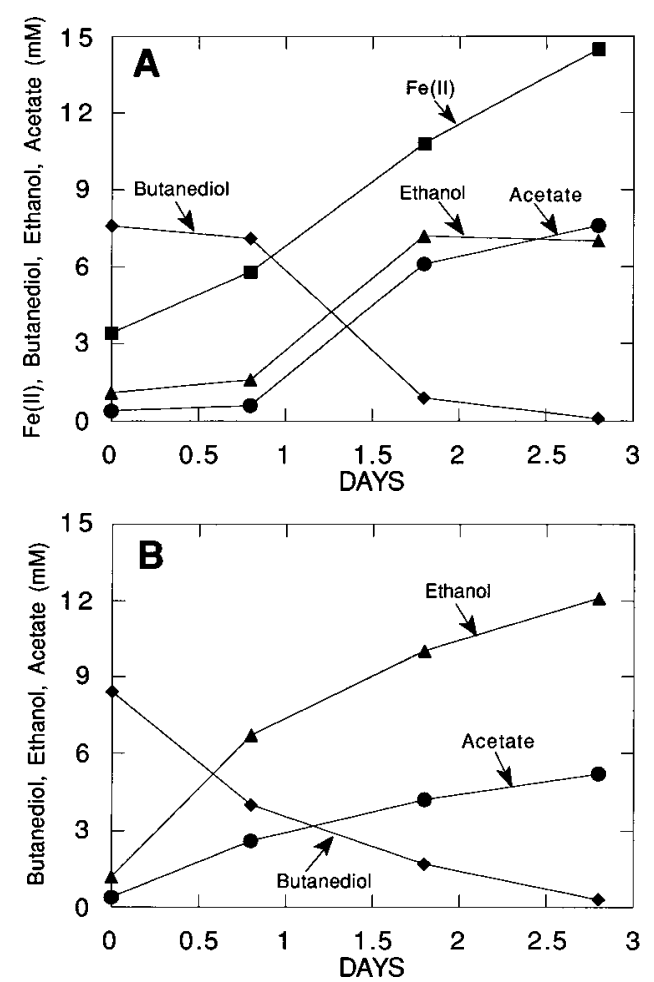

FIG. 2. Metabolism of 2,3-butanediol in the presence (A) and absence (B) of Fe(III)-NTA. As no two replicate cultures have the exact same lag time, in this and subsequent figures the data from one representative culture for each treatment are shown. The ca. $3 \mathrm{mM} \mathrm{Fe(II)} \mathrm{at} \mathrm{time} \mathrm{zero} \mathrm{in} \mathrm{this} \mathrm{and} \mathrm{subsequent}$ experiments results from the addition of the sulfide reductant which chemically reduces $\mathrm{Fe}(\mathrm{III})$.

as the electron donor, $P$. carbinolicus reduced poorly crystalline $\mathrm{Fe}(\mathrm{III})$ oxide but not $\mathrm{Fe}(\mathrm{III})$ citrate.

$P$. carbinolicus also grew in medium in which $\mathrm{H}_{2}$ was provided as an electron donor with acetate as the carbon source (Fig. 4). In five replicate cultures, the stoichiometery of Fe(III) reduced to $\mathrm{H}_{2}$ consumed was $1.9 \pm 0.2$ (mean \pm standard deviation). This suggests that $P$. carbinolicus could conserve energy to support growth by the reaction $\mathrm{H}_{2}+2 \mathrm{Fe}(\mathrm{III}) \rightarrow 2$ $\mathrm{H}^{+}+2 \mathrm{Fe}(\mathrm{II})$. Formate also served as an electron donor for $\mathrm{Fe}(\mathrm{III})$ reduction (29).

$\mathbf{S}^{\mathbf{0}}$ reduction. Since many dissimilatory Fe(III) reducers can

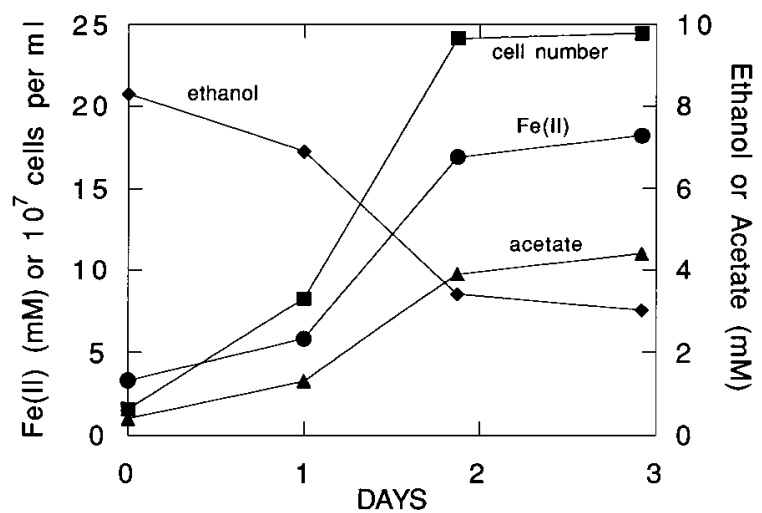

FIG. 3. Growth of $P$. carbinolicus with ethanol as the electron donor and $\mathrm{Fe}(\mathrm{III})-\mathrm{NTA}$ as the electron acceptor.

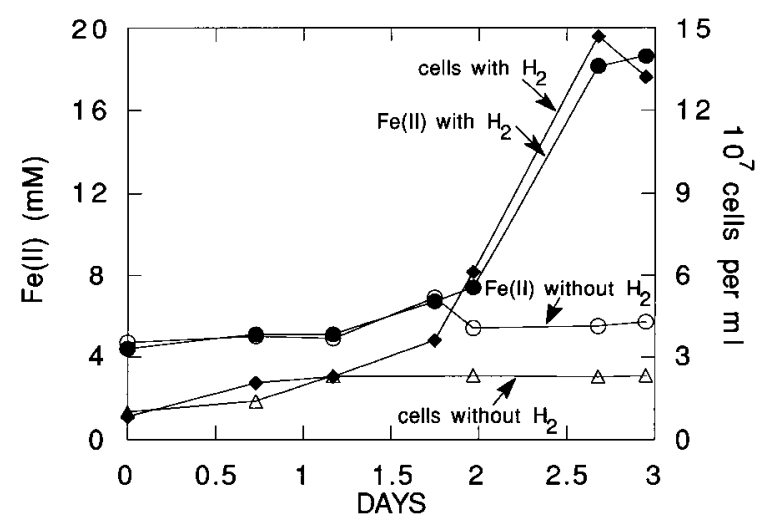

FIG. 4. Growth of P. carbinolicus with $\mathrm{H}_{2}$ as the electron donor and $\mathrm{Fe}(\mathrm{III})$ NTA as the electron acceptor.

also reduce $S^{0}(28)$, the possibility of $S^{0}$ reduction was evaluated. When $P$. carbinolicus grown on 2,3-butanediol was inoculated into 2,3-butanediol medium that also contained sublimed $\mathrm{S}^{0}$, the initial $10 \mathrm{mM}$ 2,3-butanediol was metabolized down to $3 \mathrm{mM}$ within 2 days and down to $0.3 \mathrm{mM}$ in 12 days. There was no detectable accumulation of sulfide over this period. Thus, $P$. carbinolicus was fermenting the 2,3-butanediol without significant $\mathrm{S}^{0}$ reduction.

However, when $P$. carbinolicus that had been grown on ethanol-Fe(III) was inoculated into medium in which the $\mathrm{Fe}(\mathrm{III})$ was replaced with colloidal $\mathrm{S}^{0}$ and $\mathrm{Fe}$ (II) was added as a reductant instead of sulfide, the medium turned black, indicating that sulfide was produced. $\mathrm{S}^{0}$ reduction was also observed with $\mathrm{H}_{2}$, formate, butanol, or propanol when acetate was provided as a carbon source. $\mathrm{S}^{0}$ continued to be reduced (as visually evidenced from the disappearance of $S^{0}$ ) when the ethanol- $S^{0}$ culture was transferred into ethanol- $S^{0}$ medium without added $\mathrm{Fe}(\mathrm{II}) . \mathrm{S}^{0}$ reduction was associated with cell growth (Fig. 5). Once adapted to the ethanol-colloidal $\mathrm{S}^{0}$ medium, $P$. carbinolicus also grew with sublimed $S^{0}$ as the electron acceptor (Fig. 5).

The studies of $\mathrm{Fe}(\mathrm{III})$ and $\mathrm{S}^{0}$ reduction were repeated with a fresh culture of $P$. carbinolicus from DSM with the same results.

Cytochrome content. The cytochrome content of the organism was tested because $P$. carbinolicus does not contain $c$-type cytochromes (52) but all other organisms which can conserve

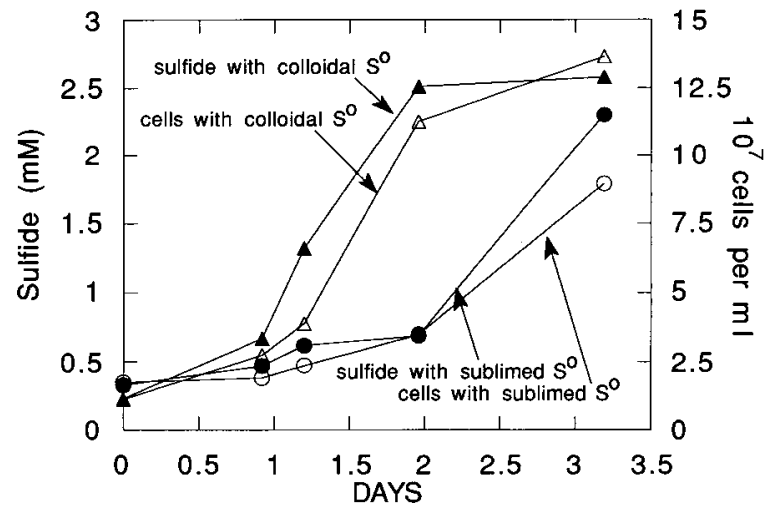

FIG. 5. Growth and sulfide production by $P$. carbinolicus with ethanol as the electron donor and colloidal $\mathrm{S}^{0}$ or sublimed $\mathrm{S}^{0}$ as the electron acceptor. 


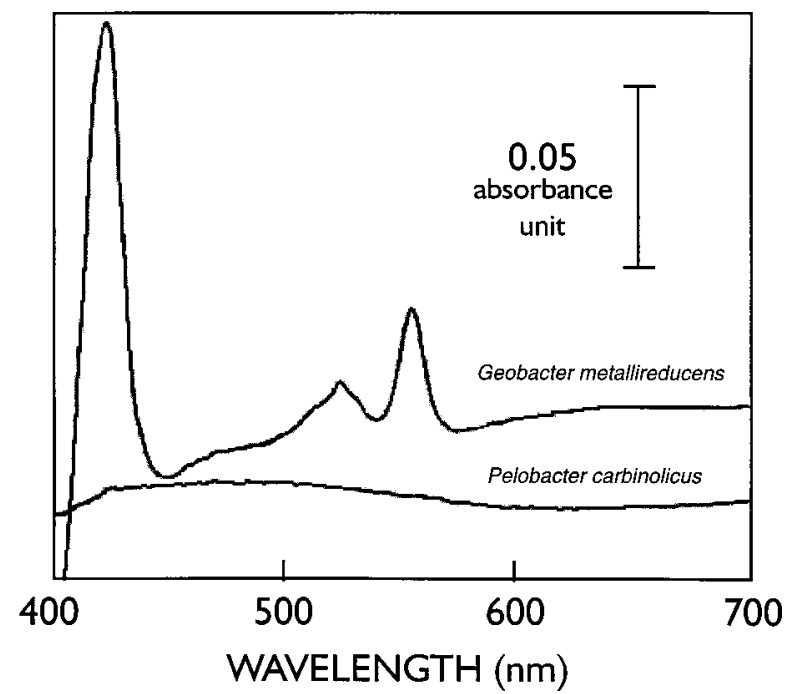

FIG. 6. Dithionite-reduced minus air-oxidized spectra of equivalent amount of cell protein $(0.2 \mathrm{mg} / \mathrm{ml})$ of $\mathrm{Fe}(\mathrm{III})$-grown $G$. metallireducens and $P$. carbinolicus.

energy to support growth from Fe(III) reduction do (28). Dithionite-reduced minus air-oxidized spectra of $\mathrm{Fe}$ (III)-grown cells gave no indication of $c$-type cytochromes whereas $c$-type cytochromes were readily apparent in a cell suspension containing an equivalent amount of $G$. metallireducens protein (Fig. 6). There was also no evidence of $c$-type cytochromes in $\mathrm{S}^{0}$-grown cells of $P$. carbinolicus (29).

$16 S$ rRNA sequence. In order to further confirm that the organism being studied was $P$. carbinolicus, the $16 \mathrm{~S}$ rRNA gene of the original culture used in these investigations was sequenced. The $16 \mathrm{~S}$ rRNA gene of the $\mathrm{Fe}(\mathrm{III})$ - and $\mathrm{S}^{0}$-reducing microorganism $D$. acetexigens was also sequenced for reference purposes. Analysis of the sequences indicated that, in agreement with previous phylogenetic placement of $P$. carbinolicus based on 16S rRNA oligonucleotide cataloging (57), the organism was in the delta Proteobacteria, closely related to $D$. acetexigens and $P$. acetylenicus (Fig. 7). Another nearly complete $16 \mathrm{~S}$ rRNA sequence of $P$. carbinolicus has recently been reported (26) and is virtually identical, with only seven unambiguous differences in the 1,417 positions that could be considered.

\section{DISCUSSION}

This study demonstrates that, in contrast to its previous designation as a solely fermentative organism (52), P. carbinolicus can use $\mathrm{Fe}(\mathrm{III})$ or $\mathrm{S}^{0}$ as a terminal electron acceptor. Thus, there are some physiological similarities between $P$. carbinolicus and organisms in the closely related Geobacter and Desulfuromonas genera. It seems likely that the common ancestor of these organisms was an $\mathrm{Fe}(\mathrm{III})$ - and $\mathrm{S}^{0}$-reducing microorganism. The results further emphasize the potential of 16S rRNA-based phylogeny to predict previously unsuspected physiological capabilities.

There are several reasons why the ability of $P$. carbinolicus to reduce $\mathrm{Fe}(\mathrm{III})$ and $\mathrm{S}^{0}$ was not observed previously. Despite growing awareness of dissimilatory $\mathrm{Fe}(\mathrm{III})$ reduction as an environmentally important process, $\mathrm{Fe}$ (III) is not routinely tested as an electron acceptor in many characterization studies. There was little reason to evaluate the potential for P. carbinolicus to reduce $\mathrm{Fe}(\mathrm{III})$ when it was isolated in the early 1980s,

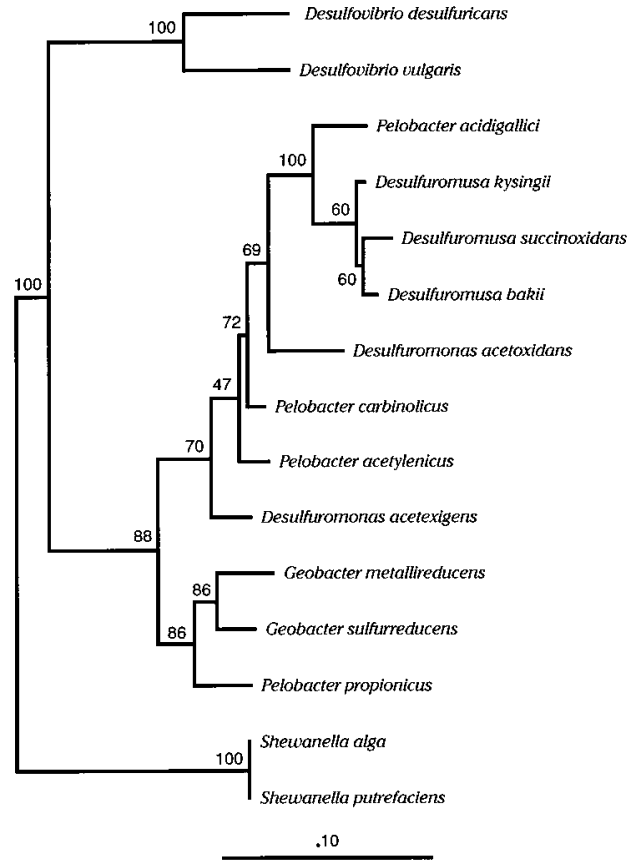

FIG. 7. Phylogenetic tree inferred from 16S rRNA sequences. Bootstrap values from 100 bootstrap analyses are given at branch nodes. A total of 1,161 positions were considered. Bar length represents $1 \%$ sequence difference.

as the capacity for microorganisms to conserve energy to support growth by coupling the oxidation of organic compounds to the reduction $\mathrm{Fe}$ (III) was not yet known. The previously reported lack of $S^{0}$ reduction is in accordance with the studies reported here in that when $P$. carbinolicus is transferred from a medium in which it is growing fermentatively to the same medium with sublimed $\mathrm{S}^{0}$, it continues to grow fermentatively. Reduction of $S^{0}$ after direct transfer from fermentative medium is observed only with colloidal $S^{0}$. This form of $S^{0}$ is not typically used in screening electron acceptors of novel organisms. Once adapted to $\mathrm{S}^{0}$ reduction with colloidal $\mathrm{S}^{0}, P$. carbinolicus readily reduces sublimed $\mathrm{S}^{0}$.

Electron transport to $\mathrm{Fe}(\mathrm{III})$. $\mathrm{Fe}$ (III) reduction by $P$. carbinolicus appears to be enzymatically catalyzed. The finding that $P$. carbinolicus could also reduce $\mathrm{S}^{0}$ raised the issue of whether $P$. carbinolicus might be indirectly reducing $\mathrm{Fe}(\mathrm{III})$ because $\mathrm{S}^{0}$ was present in the $\mathrm{Fe}$ (III) medium as the result of the $\mathrm{Fe}(\mathrm{III})$ oxidizing the sulfide that was added to the medium as a reductant. Thus, it seemed possible that $P$. carbinolicus was reducing the $S^{0}$ in the $\mathrm{Fe}$ (III) medium to sulfide which then chemically reduced $\mathrm{Fe}$ (III) with the regeneration of $\mathrm{S}^{0}$. However, subsequent studies have indicated that such cycling is not an effective mechanism for $\mathrm{Fe}(\mathrm{III})$ reduction in our culturing system because when organisms which reduce $\mathrm{S}^{0}$ but not $\mathrm{Fe}$ (III) are incubated in medium in which $\mathrm{Fe}(\mathrm{III})$ is provided as the electron acceptor and sulfide is added as a reductant there is not sustained Fe(III) reduction (29). Furthermore, as shown here, washed cell suspensions of $P$. carbinolicus reduced Fe(III) in sulfur-free buffer, demonstrating that $\mathrm{Fe}$ (III) is still reduced when the potential for sulfide acting as the $\mathrm{Fe}$ (III) reductant is eliminated.

The ability of $P$. carbinolicus to conserve energy to support growth by oxidizing ethanol to acetate with the reduction of $\mathrm{Fe}$ (III) may not be that surprising given a previous report (52) that $P$. carbinolicus can grow on ethanol in syntrophic associ- 
ation with $\mathrm{H}_{2}$-consuming microorganisms. In that metabolism, $P$. carbinolicus disposes of electrons derived from ethanol oxidation by reducing $\mathrm{H}^{+}$to $\mathrm{H}_{2}$. The $\mathrm{H}_{2}$-consuming microorganisms are necessary in order to maintain $\mathrm{H}_{2}$ concentrations low enough for $\mathrm{H}^{+}$reduction to be thermodynamically favorable. In a similar manner, $P$. carbinolicus oxidizes propanol and butanol to propionate and butyrate, respectively, if acetate is provided as a carbon source (52). Energy to support growth of $P$. carbinolicus during syntrophic growth on alcohols is assumed to come from substrate-level phosphorylation. Fe(III) could merely be substituting for $\mathrm{H}^{+}$in alcohol metabolism, even potentially being reduced by the same enzyme. Thus, the ability of $P$. carbinolicus to grow via ethanol oxidation coupled to $\mathrm{Fe}(\mathrm{III})$ reduction does not necessarily indicate that $P$. carbinolicus can conserve energy to support growth from electron transport to $\mathrm{Fe}(\mathrm{III})$.

In contrast, substrate-level phosphorylation is unlikely to be the mechanism for energy conservation during growth of $P$. carbinolicus via $\mathrm{H}_{2}$ oxidation coupled to $\mathrm{Fe}(\mathrm{III})$ reduction. The ability of microorganisms to conserve energy to support growth by oxidizing $\mathrm{H}_{2}$ with the reduction of $\mathrm{Fe}$ (III) is well known (3, $7,8,37,51)$. However, the electron transport pathway from $\mathrm{H}_{2}$ to $\mathrm{Fe}(\mathrm{III})$ in these organisms is yet to be elucidated.

Numerous studies have suggested that $c$-type cytochromes are involved in electron transport to $\mathrm{Fe}(\mathrm{III})$ in $\mathrm{H}_{2}$-oxidizing $\mathrm{Fe}$ (III) reducers as well as in $\mathrm{Fe}$ (III) reducers which conserve energy to support growth by oxidizing acetate with the reduction of $\mathrm{Fe}(\mathrm{III})(1,13,30,44,46,50)$. However, in all of these studies, the evidence for cytochrome involvement in electron transport to $\mathrm{Fe}(\mathrm{III})$ is indirect and circumstantial. For example, $c$-type cytochromes were implicated in electron transport to $\mathrm{Fe}$ (III) in G. metallireducens and D. acetoxidans based on the finding that the addition of $\mathrm{Fe}$ (III) to cell suspensions oxidized the $c$-type cytochromes $(30,50)$. However, such an oxidation may not reflect physiological electron transport as oxygen, which does not support growth of these organisms, had a similar effect. The $c_{3}$ cytochrome from Desulfovibrio vulgaris has been identified as a U(VI) and $\mathrm{Cr}(\mathrm{VI})$ reductase as well as a possible $\mathrm{Fe}(\mathrm{III})$ reductase, but this organism cannot grow with metals as the sole electron acceptor $(27,36,40)$.

The finding that $P$. carbinolicus can conserve energy to support growth from $\mathrm{Fe}$ (III) reduction and yet lacks detectable levels of $c$-type cytochromes suggests that $c$-type cytochromes are not always necessary for energy-conserving electron transport to Fe(III). Given the close phylogenetic relationship of $P$. carbinolicus to the Fe(III)-reducing Geobacter and Desulfuromonas species, it is conceivable that the $c$-type cytochromes that are prevalent in the Geobacter and Desulfuromonas species are not directly involved in electron transport to Fe(III).

Comparison of $P$. carbinolicus with Geobacter, Desulfuromonas, and Desulfuromusa species. In addition to differences in cytochrome content, $P$. carbinolicus is unlike all known Fe(III)reducing Geobacter and Desulfuromonas species in its inability to completely oxidize acetate to carbon dioxide with $\mathrm{Fe}(\mathrm{III})$ as the electron acceptor. Furthermore, the Geobacter and Desulfuromonas species that metabolize ethanol oxidize it completely to carbon dioxide $(35,49)$. Although Desulfuromonas species (59) and the first species of Geobacter isolated, $G$. metallireducens (30), cannot use $\mathrm{H}_{2}$ as an electron donor, three subsequently isolated Geobacter species are similar to $P$. carbinolicus in that they can use $\mathrm{H}_{2}$ as an electron donor for $\mathrm{Fe}(\mathrm{III})$ reduction $(8,10)$. Furthermore, a Desulfuromonas species which can oxidize $\mathrm{H}_{2}$ with the reduction of $\mathrm{Fe}(\mathrm{III})$ has been isolated (11). None of the Geobacter species that have been evaluated have been found to have the capacity to ferment 2,3-butanediol or to oxidize ethanol in coculture with a
$\mathrm{H}_{2}$-consuming methanogen (10). Although D. acetoxidans can grow fermentatively with malate, fumarate, or betaine $(20,49)$, none of the Desulfuromonas species that have been evaluated have the capacity to ferment any of the substrates fermented by Pelobacter species (57).

Since the completion of the studies reported here, the new genus Desulfuromusa, which is closely related to the GeobacterDesulfuromonas-Pelobacter group (Fig. 7), has been described (26). Each of the three Desulfuromusa species is capable of $S^{0}$ reduction. One of the species, Desulfuromusa kysingii, can reduce $\mathrm{Fe}$ (III)-citrate, but data demonstrating growth with $\mathrm{Fe}(\mathrm{III})$ as the electron acceptor were not presented or discussed $(18,26)$. The other two species, Desulfuromusa bakii and Desulfuromusa succinoxidans, cannot reduce Fe(III)-citrate. However, although some $\mathrm{Fe}(\mathrm{III})$ reducers can use $\mathrm{Fe}(\mathrm{III})$-citrate as an $\mathrm{Fe}(\mathrm{III})$ source $(8,35,37)$, not all can. As reported here, $P$. carbinolicus did not reduce $\mathrm{Fe}(\mathrm{III})$ citrate and neither did D. acetoxidans (50), D. acetexigens (29), Desulfovibrio desulfuricans (38), nor a recently isolated Geobacter species (10). It seems likely that, when other Fe(III) forms are evaluated, all of the species in the Desulfuromusa group will be found to be able to conserve energy to support growth from $\mathrm{Fe}(\mathrm{III})$ reduction.

Ecological considerations. These findings extend the known potential biogeochemical contributions of $P$. carbinolicus in sedimentary environments. The substrates on which $P$. carbinolicus can grow fermentatively, acetoin, 2,3-butanediol, and ethylene glycol, are not likely to be abundant in aquatic sediments. Thus, the primary role of $P$. carbinolicus in sediments was considered to be as an ethanol-oxidizing organism living syntrophically with $\mathrm{H}_{2}$ consumers (54). However, the results presented here demonstrate that $P$. carbinolicus could also be living in some sediments as a dissimilatory $\mathrm{Fe}(\mathrm{III})$ and/or $\mathrm{S}^{0}$ reducer. $\mathrm{H}_{2}$ is generally considered to be a much more significant intermediate than ethanol in the anaerobic metabolism of organic matter in sediments and thus would be the most likely electron donor for growth of $P$. carbinolicus on $\mathrm{Fe}(\mathrm{III})$ and/or $\mathrm{S}^{0}$.

Until recently, the most commonly isolated $\mathrm{H}_{2}$-oxidizing $\mathrm{Fe}(\mathrm{III})$-reducing microorganisms were Shewanella species (7, $37,51)$. These facultative anaerobes which are in the gamma Proteobacteria $(42,51)$ can readily be recovered from sedimentary environments $(14,45,47)$. However, it remains to be determined whether Shewanella and other facultative Fe(III)reducing microorganisms (3) are the predominant $\mathrm{H}_{2}$-oxidizing $\mathrm{Fe}(\mathrm{III})$ reducers in most sediments or whether this process is catalyzed primarily by strict anaerobes such as several Geobacter species $(8,10)$, Desulfovibrio species $(12,38)$, and $P$. carbinolicus.

$P$. carbinolicus is the first example of an organism that can conserve energy to support growth from $\mathrm{Fe}(\mathrm{III})$ reduction that can also grow syntrophically with $\mathrm{H}_{2}$-consuming microorganisms. This finding has implications for the mechanisms for inhibition of methane production in the presence of $\mathrm{Fe}(\mathrm{III})$. The ultimate factor limiting methane production under steadystate conditions in Fe(III)-containing sediments is the ability of $\mathrm{H}_{2}$ - and acetate-oxidizing microorganisms to maintain the concentrations of $\mathrm{H}_{2}$ and acetate too low for methanogens to metabolize (34). However, the ability of $\mathrm{H}_{2}$-producing acetogens to switch from $\mathrm{H}_{2}$ production to $\mathrm{Fe}(\mathrm{III})$ reduction when $\mathrm{Fe}(\mathrm{III})$ becomes available suggests that another mechanism limiting methanogenesis might be lower rates of $\mathrm{H}_{2}$ production as the result of $\mathrm{H}^{+}$-reducing organisms switching to $\mathrm{Fe}(\mathrm{III})$ reduction. Other organisms which are likely to respond in a similar manner are Desulfovibrio species which can also grow 
syntrophically via $\mathrm{H}_{2}$ production (6) and can reduce $\mathrm{Fe}(\mathrm{III})$ $(12,38)$.

In summary, this study adds only the second marine microorganism (after D. acetoxidans [50]) to the short but growing list of strict anaerobic microorganisms capable of conserving energy to support growth from Fe(III) reduction. Another marine $\mathrm{Fe}(\mathrm{III})$ reducer, D. palmitatis, was recently directly isolated from marine sediments with $\mathrm{Fe}(\mathrm{III})$ as the electron acceptor (11). Preliminary results indicate that $P$. acetylenicus and $P$. venetianus, the two species most closely related to $P$. carbinolicus (57), can also reduce Fe(III) (29). Thus, the ability to use $\mathrm{Fe}(\mathrm{III})$ as a terminal electron acceptor appears to be a highly conserved characteristic within the Geobacter-Desulfuromonas-Pelobacter group. The fact that $\mathrm{Fe}$ (III) reducers from this branch of the delta Proteobacteria have been isolated from such a wide variety of aquatic sediments and aquifers with different enrichment and isolation techniques, including different electron acceptors, suggests that the organisms within this tight phylogenetic assemblage are important components of many sedimentary environments.

\section{ACKNOWLEDGMENTS}

We thank Sue Lootens and Harry Jenter for help with the sequence analysis.

This research was supported by Office of Naval Research grant N00014-93-F-0103 and the USGS National Research Program.

\section{REFERENCES}

1. Arnold, R. G. T. J. DiChristina, and M. R. Hoffmann. 1986. Inhibitor studies of dissimilative $\mathrm{Fe}$ (III) reduction by Pseudomonas sp. strain 200 ("Pseudomonas ferrireductans"). Appl. Environ. Microbiol. 52:281-289.

2. Ausubel, F., R. Brent, R. E. Kingston, D. D. Moore, J. G. Seidman, J. A. Smith, and K. Struhl. 1992. Short protocols in molecular biology. John Wiley and Sons, New York.

3. Balashova, V. V., and G. A. Zavarzin. 1980. Anaerobic reduction of ferric iron by hydrogen bacteria. Microbiology 48:635-639.

4. Balch, W. E., G. E. Fox, L. J. Magrum, C. R. Woese, and R. S. Wolfe. 1979. Methanogens: reevaluation of a unique biological group. Microbiol. Rev. 43:260-296.

5. Blumentals, I. I., M. Itoh, G. J. Olson, and R. M. Kelly, 1990. Role of polysulfides in reduction of elemental sulfur by the hyperthermophilic archaebacterium Pyrococcus furiosus. Appl. Environ. Microbiol. 56:1255-1262.

6. Bryant, M. P., L. L. Campbell, C. A. Reddy, and M. R. Crabill. 1977. Growth of Desulfovibrio in lactate or ethanol media low in sulfate in association with $\mathrm{H}_{2}$-utilizing methanogenic bacteria. Appl. Environ. Microbiol. 33:1162-1169.

7. Caccavo, F., Jr., R. P. Blakemore, and D. R. Lovley. 1992. A hydrogenoxidizing, $\mathrm{Fe}$ (III)-reducing microorganism from the Great Bay Estuary, New Hampshire. Appl. Environ. Microbiol. 58:3211-3216.

8. Caccavo, F., Jr., D. J. Lonergan, D. R. Lovley, M. Davis, J. F. Stolz, and M. J. McInerney. 1994. Geobacter sulfurreducens sp. nov., a hydrogen- and acetateoxidizing dissimilatory metal-reducing microorganism. Appl. Environ. Microbiol. 60:3752-3759.

9. Cline, J. D. 1969. Spectrophotometric determination of hydrogen sulfide in natural waters. Limnol. Oceanogr. 14:454-458.

10. Coates, J. D. Unpublished data.

11. Coates, J. D., D. J. Lonergan, H. L. Jenter, and D. R. Lovley. Desulfuromonas palmitatis sp. nov., a long-chain fatty acid oxidizing Fe(III) reducer from marine sediments. Submitted for publication.

12. Coleman, M. L., D. B. Hedrick, D. R. Lovley, D. C. White, and K. Pye. 1993. Reduction of $\mathrm{Fe}(\mathrm{III})$ in sediments by sulphate-reducing bacteria. Nature (London) 361:436-438.

13. DiChristina, T. J., R. G. Arnold, M. E. Lidstrom, and M. R. Hoffmann. 1988. Dissimilative iron reduction by the marine eubacterium Alteromonas putrefaciens strain 200. Water Sci. Technol. 20:69-79.

14. DiChristina, T. J., and E. F. DeLong. 1993. Design and application of rRNA-targeted oligonucleotide probes for dissimilatory iron- and manganese-reducing bacterium Shewanella putrefaciens. Appl. Environ. Microbiol. 59:4152-4160.

15. Eden, P. E., T. M. Schmidt, R. P. Blakemore, and N. R. Pace. 1991. Phylogenetic analysis of Aquaspirillum magnetotacticum using polymerase chain reactionamplified 16S rRNA-specific DNA. Int. J. Syst. Bacteriol. 41:324-325.

16. Evers, S., M. Weizenegger, W. Ludwig, B. Schink, and K.-H. Schleifer. 1993. The phylogenetic positions of Pelobacter acetylenicus and Pelobacter propionicus. Syst. Appl. Microbiol. 16:216-218.
17. Felstein, J. 1981. Evolutionary trees from DNA sequences: a maximum likelihood approach. J. Mol. Evol. 17:368-376.

18. Finster, K., and F. Bak. 1993. Complete oxidation of propionate, valerate, succinate, and other organic compounds by newly isolated types of marine, anaerobic, mesophilic, gram-negative, sulfur-reducing eubacteria. Appl. Environ. Microbiol. 59:1452-1460.

19. Finster, K., F. Bak, and N. Pfennig. 1994. Desulfuromonas acetexigens sp. nov., a dissimilatory sulfur-reducing eubacterium from anoxic freshwater sediments. Arch. Microbiol. 161:328-332.

20. Heijthuijsen, J. H. F. G., and T. A. Hansen. 1989. Betaine fermentation and oxidation by marine Desulfuromonas strains. Appl. Environ. Microbiol. 55: 965-969.

21. Hobbie, J. E., R. J. Daley, and S. Jasper. 1977. Use of Nuclepore filters for counting bacteria by fluorescence microscopy. Appl. Environ. Microbiol. 33:1225-1228.

22. Hungate, R. E. 1969. A roll tube method for cultivation of strict anaerobes. Methods Microbiol. 3B:117-132.

23. Lane, D. J., K. G. Field, G. J. Olsen, and N. R. Pace. 1988. Reverse transcriptase sequencing of ribosomal RNA for phylogenetic analysis. Methods Enzymol. 167:138-144.

24. Lane, D. L., B. Pace, G. J. Olsen, D. Stahl, M. L. Sogin, and N. R. Pace. 1985 Rapid determination of 16S ribosomal RNA sequences for phylogenetic analysis. Proc. Natl. Acad. Sci. USA 82:6955-6959.

25. Larson, N., G. J. Olsen, B. L. Maidak, M. J. McCaughey, R. Overbeek, T. Macke, T. L. Marsh, and C. R. Woese. 1993. The ribosomal database project. Nucleic Acids Res. 21:3021-3023.

26. Liesack, W., and K. Finster. 1994. Phylogenetic analysis of five strains of gram-negative, obligately anaerobic, sulfur-reducing bacteria and description of Desulfuromusa gen. nov., including Desulfuromusa kysingii sp. nov., De sulfuromusa bakii sp. nov., and Desulfuromusa succinoxidans sp. nov. Int. J. Syst. Bacteriol. 44:753-758.

27. Lovley, D. R. 1993. Dissimilatory metal reduction. Annu. Rev. Microbiol. 47:263-290.

28. Lovley, D. R. 1994. Microbial reduction of iron, manganese, and other metals. Adv. Agron. 54:175-231.

29. Lovely, D. R. Unpublished data

30. Lovley, D. R., S. J. Giovannoni, D. C. White, J. E. Champine, E. J. P. Phillips, Y. A. Gorby, and S. Goodwin. 1993. Geobacter metallireducens gen. nov. sp. nov., a microorganism capable of coupling the complete oxidation of organic compounds to the reduction of iron and other metals. Arch. Microbiol. 159:336-344

31. Lovley, D. R., and S. Goodwin. 1988. Hydrogen concentrations as an indicator of the predominant terminal electron accepting reactions in aquatic sediments. Geochim. Cosmochim. Acta 52:2993-3003.

32. Lovley, D. R., R. C. Greening, and J. G. Ferry. 1984. Rapidly growing rumen methanogenic organism that synthesizes coenzyme $\mathrm{M}$ and has a high affinity for formate. Appl. Environ. Microbiol. 48:81-87.

33. Lovley, D. R., and E. J. P. Phillips. 1986. Organic matter mineralization with reduction of ferric iron in anaerobic sediments. Appl. Environ. Microbiol. 51:683-689.

34. Lovley, D. R., and E. J. P. Phillips. 1987. Competitive mechanisms for inhibition of sulfate reduction and methane production in the zone of ferric iron reduction in sediments. Appl. Environ. Microbiol. 53:2636-2641.

35. Lovley, D. R., and E. J. P. Phillips. 1988. Novel mode of microbial energy metabolism: organic carbon oxidation coupled to dissimilatory reduction of iron or manganese. Appl. Environ. Microbiol. 54:1472-1480.

36. Lovley, D. R., and E. J. P. Phillips. 1994. Reduction of chromate by Desulfovibrio vulgaris and its $c_{3}$ cytochrome. Appl. Environ. Microbiol. 60:726-728.

37. Lovley, D. R., E. J. P. Phillips, and D. J. Lonergan. 1989. Hydrogen and formate oxidation coupled to dissimilatory reduction of iron or manganese by Alteromonas putrefaciens. Appl. Environ. Microbiol. 55:700-706.

38. Lovley, D. R., E. E. Roden, E. J. P. Phillips, and J. C. Woodward. 1993 Enzymatic iron and uranium reduction by sulfate-reducing bacteria. Mar. Geol. 113:41-53.

39. Lovley, D. R., J. F. Stolz, G. L. Nord, and E. J. P. Phillips. 1987. Anaerobic production of magnetite by a dissimilatory iron-reducing microorganism. Nature (London) 330:252-254.

40. Lovley, D. R., P. K. Widman, J. C. Woodward, and E. J. P. Phillips. 1993 Reduction of uranium by cytochrome $c_{3}$ of Desulfovibrio vulgaris. Appl Environ. Microbiol. 59:3572-3576.

41. Lowry, O. H., N. J. Rosebrough, A. L. Farr, and R. J. Randall. 1951. Protein measurement with the Folin phenol reagent. J. Biol. Chem. 193:265-275.

42. MacDonell, M. T., and R. R. Colwell. 1985. A phylogeny for the Vibrionaceae, and recommendation for two new genera, Listonella and Shewanella. Syst. Appl. Microbiol. 6:171-182.

43. Miller, T. L., and M. J. Wolin. 1974. A serum bottle modification of the Hungate technique for cultivating obligate anaerobes. Appl. Microbiol. 27: 985-987.

44. Myers, C. R., and J. M. Myers. 1992. Localization of cytochromes to the outer membrane of anaerobically grown Shewanella putrefaciens MR-1. J. Bacteriol. 174:3429-3438.

45. Myers, C. R., and K. H. Nealson. 1988. Bacterial manganese reduction and 
growth with manganese oxide as the sole electron acceptor. Science 240: 1319-1321.

46. Obuekwe, C. O., and D. W. S. Westlake. 1982. Effects of medium composition on cell pigmentation, cytochrome content, and ferric iron reduction in a Pseudomonas sp. isolated from crude oil. Can. J. Microbiol. 28:989-992.

47. Obuekwe, C. O., D. W. S. Westlake, and F. D. Cook. 1981. Effect of nitrate on reduction of ferric iron by a bacterium isolated from crude oil. Can. J. Microbiol. 27:692-697.

48. Olsen, G. J., H. Matsuda, R. Hagstrom, and R. Overbeek. 1994. fastDNAml: a tool for construction of phylogenetic trees of DNA sequences using maximum likelihood. Comput. Appl. Biosci. 10:41-48.

49. Pfennig, N., and H. Biebl. 1976. Desulfuromonas acetoxidans gen. nov. and sp. nov., a new anaerobic, sulfur-reducing, acetate-oxidizing bacterium. Arch. Microbiol. 110:3-12.

50. Roden, E. E., and D. R. Lovley. 1993. Dissimilatory Fe(III) reduction by the marine microorganism, Desulfuromonas acetoxidans. Appl. Environ. Microbiol. 59:734-742.

51. Rossello-Mora, R. A., F. J. Caccavo, K. Osterlehner, N. Springer, S. Spring, D. Schuler, W. Ludwig, R. Amann, M. Vannacanneyt, and K. H. Schleifer. 1994. Isolation and taxonomic characterization of a halotolerant, facultatively iron-reducing bacterium. Syst. Appl. Microbiol. 17:569-573.

52. Schink, B. 1984. Fermentation of 2,3-butanediol by Pelobacter carbinolicus sp. nov. and Pelobacter propionicus sp. nov., and evidence for propionate formation from $\mathrm{C}_{2}$ compounds. Arch. Microbiol. 137:33-41.
53. Schink, B. 1985. Fermentation of acetylene by an obligate anaerobe, Pelobacter acetylenicus $\mathrm{sp}$. nov. Arch. Microbiol. 142:295-301.

54. Schink, B. 1992. The genus Pelobacter, p. 3393-3399. In A. Balows, H. G. Truper, M. Dworkin, W. Harder, and K.-H. Schleifer (ed.), The procaryotes. Springer-Verlag, New York.

55. Schink, B., and N. Pfennig. 1982. Fermentation of trihydroxybenzenes by Pelobacter acidigallici gen. nov. sp. nov., a new strictly anaerobic, non-sporeforming bacterium. Arch. Microbiol. 133:195-201.

56. Schink, B., and M. Stieb. 1983. Fermentative degradation of polyethylene glycol by a strictly anaerobic, gram-negative, nonsporeforming bacterium, Pelobacter venetianus sp. nov. Appl. Environ. Microbiol. 45:1905-1913.

57. Stackebrandt, E., U. Wehmeyer, and B. Schink. 1989. The phylogenetic status of Pelobacter acidigallici, Pelobacter venetianus, and Pelobacter carbinolicus. Syst. Appl. Microbiol. 11:257-260.

58. Weisburg, W. G., S. M. Barns, D. A. Pelletier, and D. J. Lane. 1991. 16S ribosomal DNA amplification for phylogenetic study. J. Bacteriol. 173:697703.

59. Widdel, F. 1988. Microbiology and ecology of sulfate- and sulfur-reducing bacteria, p. 469-585. In A. J. B. Zehnder (ed.), Biology of anaerobic microorganisms. John Wiley \& Sons, New York.

60. Widdel, F., and N. Pfennig. 1992. The genus Desulfuromonas and other gram-negative sulfur-reducing eubacteria, p. 3379-3392. In A. Balows, H. G. Truper, M. Dworkin, W. Harder, and K.-H. Schleifer (ed.), The prokaryotes. Springer-Verlag, New York. 